\title{
Identification of Premature Deindustrialization and Its Acceleration in Indonesia (Period 1986-2015)
}

\author{
Vina Eka Andriyani ${ }^{1}$, Tony Irawan ${ }^{2}$ \\ ${ }^{1}$ Central Bureau of Statistics
}

Jl. Dr. Sutomo 6-8, Pasar Baru, Jakarta Pusat, DKI Jakarta 10710, Indonesia

${ }^{2}$ Department of Economics, Bogor Agricultural University

J1. Kamper, Kampus IPB Darmaga, Gedung FEM Lt. II, Bogor 16680

[received: 1 July 2018 - revised 20 July 2018 - available online: 1 August 2018]

\begin{abstract}
ABSTRAK
Peningkatan kontribusi manufaktur dalam PDB telah mencapai puncaknya pada awal tahun 2000an sementara tingkat pertumbuhan lapangan kerja pada sektor manufaktur relatif rendah. Kedua fakta tersebut menunjukkan bahwa proses industrialisasi telah melambat dan hal tersebut mengindikasikan adanya deindustrialisasi di Indonesia. Deindustrialisasi yang terjadi di negara-negara dengan PDB per kapita rendah disebut deindustrialisasi dini. Studi ini mengukur tingkat deindustrialisasi dan identifikasi deindustrialisasi dini pada periode 1986-2015. Hasilnya menunjukkan bahwa kecepatan deindustrialisasi bervariasi antara indikator dan antar pulau. Analisis deskriptif menunjukkan indikasi deindustrialisasi dini di Indonesia.
\end{abstract}

Kata kunci: Deindustrialisasi, Deindustrialisasi dini, Manufaktur, Indonesia

\begin{abstract}
The increase of the manufacturing's share in GDP has reached its peak in the early 2000s while the growth rate of the manufacturing employment is relatively low. Both facts demonstrate that the process of industrialization has slowed down and an indication of deindustrialization in Indonesia. Deindustrialization that occurs in the countries with low GDP per capita is called premature deindustrialization. This study measures the rate of deindustrialization and identification of premature deindustrialization on period 19862015. The result shows that the speed of deindustrialization varies between indicators and between islands. Descriptive analysis showed indication of premature deindustrialization in Indonesia.
\end{abstract}

Keywords: Deindustrialization, Premature deindustrialization, Manufacturing, Indonesia

JEL classification: L16, L50, L52, L60, O14, O25 


\section{INTRODUCTION}

Economic development is often measured by the level of progress of production structures and the rate of employment. One of the efforts to accelerate development as reflected by the rapid economic growth rate is through industrialization. Gillis et al. (1992) states that the manufacturing is a leading sector. In addition, the emergence of regional growth theory proposed by Kaldor (1966) mentions that the manufacturing sector is an engine of growth in the economic system for a country or region (Dasgupta and Singh 2006). With the industrialization, there will be a transformation of economic structure that the contribution of the agricultural sector will decline and be replaced by the increasing of the manufacturing and services contribution.

The role of the manufacturing as the engine of economic growth in Indonesia during the industrialization has been proven by the research of Dewi (2010) using Kaldorian approach. The results of research mentioned that the growth of manufacturing proved to trigger the growth of the sector beside the manufacturing so in the end the overall economic growth will grow rapidly.

Around the 1970s, the scenario of the economic structure transformation based on agriculture toward industry began to be seen. It can be seen the structure of production and employment. The employment share of agricultural sector continued to decline while at the same time the share of the manufacturing and services sectors increased. However, the increasing contribution of the manufacturing has reached its peak in early 2000s. Since then, manufacturing's share in the Indonesian economy continue to decreased. When viewed from employment side, the shifting of employment is not fully transferred to the manufacturing sector but more to the other sector.

These two facts show that the process of industrialization has slowed down and indicated the occurrence of deindustrialization in Indonesia. The decline in the share of the agricultural sector does not coincide with an increase in the share of the manufacturing sector either in GDP or employment. It means that there is an indication that the excess employment of agriculture has overflowed into the service sector, especially informal services (Priyarsono 2011).

Deindustrialization is a problem for a country. In addition to threatening Indonesia's competitiveness, deindustrialization also threatens economic growth. Since 2005, the growth of manufacturing sector is under the overall economic growth. Since then, Indonesia's economic growth has not been able to reach $7 \%$, only about 5-6 $\%$. The slower growth of manufacturing sector compared to economic growth caused the share of manufacturing to decline.

The threat of middle income trap is a warning to the government about other dangers of deindustrialization. A country experiences a middle income trap if it is in the middle income group based on the size of income per capita, but can not penetrate into the high income group ${ }^{1}$. Based on the MGI (2012) study, the middle income trap is the position of a country trapped with per capita GDP

\footnotetext{
${ }^{1}$ https://faisalbasri.com, Indonesia Terjerat Middle Income Trap, August 10, 2013
} 
below $\$ 7000$ and manufacturing can not penetrate $30 \%{ }^{2}$

Rodrik (2015) mentions that deindustrialization has been happening in developed countries, where it is associated with the loss of good jobs, rising inequality, and decline in innovation capacity. For all these and many other reasons, it should be a much bigger problem for developing countries. These developing countries have been experiencing premature deindustrialization. These countries are transformed into service-based economies without experiencing an established industrialization process.

The term premature deindustrialization was first used in Dasgupta and Singh (2006). It is called "premature deindustrialization" because deindustrialization occurs when level of income per capita of the developing countries is much lower than income per capita of the developed countries when the developed countries were in the peak period of industrialization. These situation happened in Indonesia, in the early stages, the proportion of the agricultural sector declining and replaced by the manufacturing sector in the national output. But in a short time, before the national industry grows strong and entrenched, the national economy has shifted to the services sector.

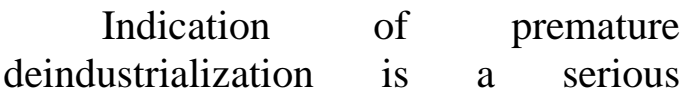
consequence to the economy and politics. On the economic side, it reduces the potential for economic growth and the possibility of convergence with income levels from developed countries. The political consequences of premature

\footnotetext{
${ }^{2}$ http://www.kompasiana.com, Deindustrialisasi Ancam Indonesia Jadi Negara Gagal, November 21,2016
}

deindustrialization can make democratization more vulnerable.

Tragenna (2015) describes the impact of premature deindustrialization for a country. First, premature deindustrialization shows that the benefits of the processing industry as a driver of a country's growth are reduced so that it will hinder the prospects for economic growth. The second impact, premature deindustrialization has the potential to threaten the potential of the service sector as an alternative to engine growth. In a mature deindustrialization, a growing service sector may have growth-driven properties owned by the manufacturing sector (such as increasing return to scale, increased cumulative productivity coverage, strong relationships with other sectors, technological advances, etc.). However, when premature deindustrialization occurs, service sector activities that may replace the manufacturing industry are more low skill, non-tradeable, retail, or have no large return-to-scale properties. Third, premature deindustrialization may occur suddenly, compared to deindustrialization in developed countries resulting from changes in government policies such as liberalization.The sudden impact of liberalization in triggering the acceleration of deindustrialization is more pronounced.

Thus, premature deindustrialization is not good news for developing countries. The impact is already evident in developing countries. In Latin America, when the manufacturing has grown slowly, causing economic productivity to suffer. In Africa, urban migrants work in the service sector with low productivity rather than 
manufacturing. In China, although the growth of Chinese investment is increasing, there are no signs of awakening in the industry. Growth occurs driven by capital inflows, transfers, or commodity booms, raises questions about its sustainability (Rodrik 2015). In addition, learning from the experiences of three countries that have been deindustrialized, it takes a long time to recover. Japan takes 10 years to recover, the United States takes 20 years, and England takes 15 years. . ${ }^{3}$

The symptoms of premature deindustrialization in Indonesia have occurred since the beginning of 2000 and are indicated to still occur today. Thus, the problem of premature deindustrialization should not be ignored. Especially the experience of developed countries that take a long time to revive the industrialization (reindustrialization). Because of that, Indonesia as an archipelagic country with different natural resourses and social conditions and also the uneven distribution of industries across archipelagic regions, the government's strategy to address deindustrialization must also be targeted, which areas should be pushed towards reindustrialization.

Based on the above description, then the issues discussed in this research are: (1) How is the rate of deindustrialization in Indonesia between time periods (decades), whether decreased or increased?, (2) What is the ratio of deindustrialization speed in Indonesia across the islands, which island region is the fastest deindustrialisation rate?, (3) Does premature deindustrialization occur in Indonesia and how is it measured?

\footnotetext{
${ }^{3}$ http://m.kontan.co.id, LIPI Indonesia Berjalan ke Arah Deindustrialisasi, December 22, 2010
}

The scope of the study area is Indonesia using 30 years data analysis from 1986 to 2015. That periode was chosen with consideration of Indonesian economy condition in the 3 decades. The data used are provincial annual data.

The limitation of this research is to analyze only the speed of indication of deindustrialization at national and island region levels and not to analyze at the provincial or industrial level. In addition, indications of premature deindustrialization are only proven by descriptive analysis. The analytical method used refers to Rodrik (2015) research.

\section{LITERATURE REVIEW}

\section{Manufacturing Concept}

Manufacturing is an economic activity/field of business in the field of chemical or physical changes of materials, elements or components into new products. Processing raw materials come from agricultural, forestry, fishery, mining or quarry products such as products from other processing industries. Basic changes, renewals or reconstructions of goods are generally treated as processing industries. The manufacturing industry unit is described as a factory, machine or equipment specifically driven by machinery and hands. Including the category of manufacturing herein is a unit that converts the material into a new product by hand, a makloon activity or a sales activity of a manufactured product in the same place where the product is sold and a unit performing the processing of materials from another party on a contractual basis (BPS, 2009). 


\section{Deindustrialization Concept}

Deindustrialialization can be interpreted as a decrease in the contribution of output/GDP of the manufacturing sector in the national income or GDP or the decline in the contribution of workers in the manufacturing sector to total workers. Some previous researchers define it partially, ie only a decrease in the contribution of the manufacturing sector workers to the total worker or only the decrease in the contribution of output / GDP of the manufacturing sector in national income or GDP.

Rowthorn and Wells (1987) in
Dewi (2010), distinguish
deindustrialization into two kinds, which
are positive and negative
deindustrialization.
deindustrialization is the impact that occurs because the economy has experienced maturity in economic development. With economic development increasing per capita income, the role of agricultural sector workers has declined and the role of the manufacturing sector workers has increased to the highest levels of development achieved. However, on the other hand, there is an increase in per capita income from the increased role of the services sector. While negative deindustrialization is a pathological phenomenon where a structural imbalance in the economy prevents a nation to achieve full employment growth. This situation occurs because of the deteriorating performance of manufacturing industry sector and the slowing growth of output and productivity of manufacturing industry sector which resulted in decreased competitiveness so that the economy is getting worse. Unemployment from the manufacturing industry sector resulting from the negative deindustrialization can not be absorbed in the service sector due to the slowing economic situation.

Bazen and Thirlwall define deindustrialization as a decrease in the number of workers in the manufacturing sector either in absolute or relative terms to total workers. The focus on the workers in the manufacturing sector is done because it is very useful to see an increase in income at a certain level of worker productivity and the relationship between industrialization and job creation. Based on the definition of deindustrialization it can be concluded that positive deindustrialization does not cause the increase in the number of unemployed while negative deindustrialization can cause the increase in the number of unemployed (Jalilian and Weiss, 2000).

Rowthorn and Ramaswany (1999) define deindustrialization as a process of reducing the contribution of industrial workers to total workers. Tragenna (2009) stated that in addition to the decline in the contribution of the manufacturing to total workers, deindustrialization is driven by a decrease in the value-added contribution of the manufacturing to GDP.

\section{Concept of U-Reversed Curve (Inverted U-Shape)}

Engel's Law states that the proportion of total expenditure devoted to food decreases with income (Nicholson 1995). Clark (1957) extends this view and points out that a country's welfare level affects the relative demand for agricultural products, processing industries and services. Based on crossnational data analysis, it is concluded that along with the increase in real incomes per capita, the relative demand of agricultural products decreases over time and the relative demand of 
manufacturing goods initially increases and then decreases with demand for services (Kollmeyer 2009).

In recent years, many researchers have supported Clark's argument (1957) with empirical data. In these studies the inverted U-shape is obtained, where for countries with low and medium income per capita in line with increasing per capita income, it will increase the relative share of the manufacturing workers, but further on the prosperity limit a certain increase in income per capita decreases the share of manufacturing workers. As for developed countries, increased welfare encourages consumers to spend a larger portion of services that in turn will lead to deindustrialization (Rowthorn and Ramaswany 1997, 1999; Rodrik 2015; Tragenna 2015; Castilllo and Neto 2016).

\section{The Concept of Premature Deindustrialization}

The term premature deindustrialization was first used in Dasgupta and Singh (2006). Premature deindustrialization occurs when the level of income per capita of the country (developing country) is much lower than per capita income of developed countries when developed countries are in the industrialization period. Rodrik (2015) mentions that premature deindustrialization occurs in developing countries because the country is transformed into a service-based country without experiencing an established industrialization process.

Tragenna (2015) defines as deindustrialization that begins when the level of GDP per capita is lower and / or when the contribution level of the manufacturing industry to employment and GDP is lower than in general international cases. Castillo and Neto
(2016) stated that premature deindustrialization occurs when the contribution of the manufacturing industry to total workforce is lower than expected for certain per capita income levels.

\section{Previous Studies}

Research on deindustrialization and premature deindustrialization in both developed and developing countries has been done by many researchers. In Indonesia, research on deindustrialization is largely concerned with the factors affecting deindustrialization with different perspectives.

Suwarman (2006) in his research on the deindustrialization process in Indonesia concluded that the process of deindustrialization in Indonesia in recent years is not a natural impact of the success of Indonesia's economic development, but rather caused by various shocks to the economic system.

Dewi (2010) in his research, aims to examine the role of the manufacturing industry sector in the Indonesian economy during the industrialization phase based on analysis with the Kaldorian approach. The result of research shows that the manufacturing sector is the engine of growth in Indonesia during the industrialization stage. The growth of manufacturing industry sector triggered growth in the sector other than the manufacturing so that eventually GDP growth will grow more rapidly. The process of deindustrialization that occurred in Indonesia since 2002 tends toward a negative direction. This negative deindustrialization is characterized by the low balance of trade (trade balance) or the openness of the economy (openness). This indicates that in general the process of deindustrialization in 
Indonesia is not a natural impact of a highly developed development process but rather caused by shocks to the Indonesian economy.

Metinara (2011) in the study of factors affecting Deindustrialization in Indonesia Year 2000-2009, show that domestic factors (per capita income and productivity growth) and economic globalization (economic openness and foreign investment) have an effect on deindustrialization in Indonesia either directly or indirectly. In addition, human capital (the number of skilled workers) also affect the deindustrialization although it does not show a significant relationship. Based on the results of research, deindustrialization that happened in Indonesia since last few years is a negative deindustrialization. The deindustrialization is not a natural impact of the development process but rather a number of shocks in the economic system.

Rasbin (2011) has analyzed the current national economy began to move toward deindustrialization. Deindustrialization symptoms in Indonesia can be seen from several indicators such as the decreased of absorption rate of employment in the industrial sector compared to the absorption of employment in other sectors such as primary sector and services, the decreased of the manufacturing's share to the national economic growth, the decline in the number of companies engaged in the industrial sector, the tendency of declining competitiveness of domestic goods production in the international market and Indonesia getting eliminated from the regional and global manufacturing industry production network. Deindustrialization will have an impact on the declining value of national industry and the erosion of economic activity, such as: Indonesia potentially becomes more consumptive, the increasing dependency on the exporting countries of manufactured goods, the difficulty of reindustrialization and the decreasing of employment rate, termination of employment and will eventually increase the number of unemployment in Indonesia.

Other studies related to deindustrialization and premature deindustrialization include:

1. Rowthorn and Ramaswamy (1997), conducted research with data from 21 OECD Countries from 23 OECD Countries (excluding Luxemberg and Iceland) during 1963, 1970, 1975, 1980, 1985, 1990 and 1994. The results of this study conclude that there is a non linear relationship between per capita income and the share of manufacturing workers so that while the economic growth continues to increase, the proportion of workers in the manufacturing sector is decreased. Deindustrialization process will affect the total productivity where it will grow based on the growth of the service sector. This situation causes the further improvements in living standards to be affected by the growth of the service sector's productivity.

2. Dasgupta and Singh (2006) conducted "Manufacturing, Services, and Premature Deindustrialization in Developing Countries: A Kaldorian Analysis" study with data from 14 developing countries, 1986-2000. The results of his research states that developing countries with per capita income at low and middle levels maintain a high income elasticity of demand for manufactured goods. A country experiencing pathological deindustrialization should evaluate its 
industry policy for more focused and targeted economic growth. Conversely, the countries with positive deindustrialization, the existing industrial policy does not need to be revised again. In this study, the term premature deindustrialization was first used, measured by the rate of attainment of GDP per capita of developing countries at the time of deindustrialization compared to the GDP per capita of developed countries when the developed countries are at the peak of industrialization.

3. Castillo and Neto (2016) conducted a study of premature deindustrialization of 4 countries in Latin America including Argentina, Brazil, Chile, and Mexico. The premature deindustrialization is measured by comparing the GDP per capita of 8 developed countries when they reach the peak of industrialization with the GDP per capita 4 countries in Latin America, which referred to as turning point. While to estimate deindustrialization, they used a simple equation of Rowthorn-Type Reggression from Rowthorn (1994) which calculates the manufacturing employment shares to the total of workforce with GDP per capita and perquised GDP per-capita (all variables in natural logarithms).

4. Rodrik (2015) conducts premature deindustrialization research for developing countries by three measurements, namely manufacturing employment share, nommva (manemp), manufacturing value added share at current prices (nommva), and manufacturing value added share at constant prices (realmva). The relationship between the three measurements of industrialization and income per capita is shown by an inverted $U$ shaped curve or also called hump shape. The curve is made base on quadratic estimates (population logs and GDP per capita) using fixed effects and dummy models. His research aims to examine whether the deindustrialization occurring in developing countries is becoming faster for the present. Using dummy for time period of 1960, 1970, 1980, 1990, and post-2000. The research also see deindustrialization within different country groups of developed countries. The results of his research, showed deindustrialization more clearly indicated from employment conditions. This led him to analyze more deeply about deindustrialization of employment based on skill groups. Premature deindustrialization obtained by comparing the achievement of peak levels of industrialization among country with late industrializers and early industrializers, as measured by manemp and realmva. The result is late industrializers country peaked at the industrialization level shown by lower income levels than early industrialized country. Each country's peak level was determined visually, which is when the manemp starts to decline.

5. Tragenna (2015) states that there are two key aspects linking deindustrialization, these are the level of per capita income of a country and how high the contribution of manufacturing to employment and GDP at the time of deindustrialization. Conceptually both aspects are inverted $\mathrm{U}$. The first aspect shows how far to right (referring to how high income per capita) when in the turning point, the second aspect of how high the turning 
point (the contribution of manufacturing to employment and GDP). Based on these concepts, a basic calculation for premature deindustrialization with simple approach of the Rowthorn-Type Regression (Rowthorn, 1994) is established. Dependent variable is used the contribution of Manufacturing employment to the total employment, and explanatory variables are GDP per capita and GDP per capita squared (all in natural logarithmic).

\section{Framework}

The process of industrialization in Indonesia began in the late 1980s (Dasril, 1993). The development of economic conditions up to 2008 based on the criteria of industrialized countries and the criteria of United Nations Industrial Development Organization (UNIDO) shows that the industrialization process in Indonesia has not been completed yet. This is shown by the absence of Indonesia in the category of industrialized countries (Ruky in Dewi 2010).

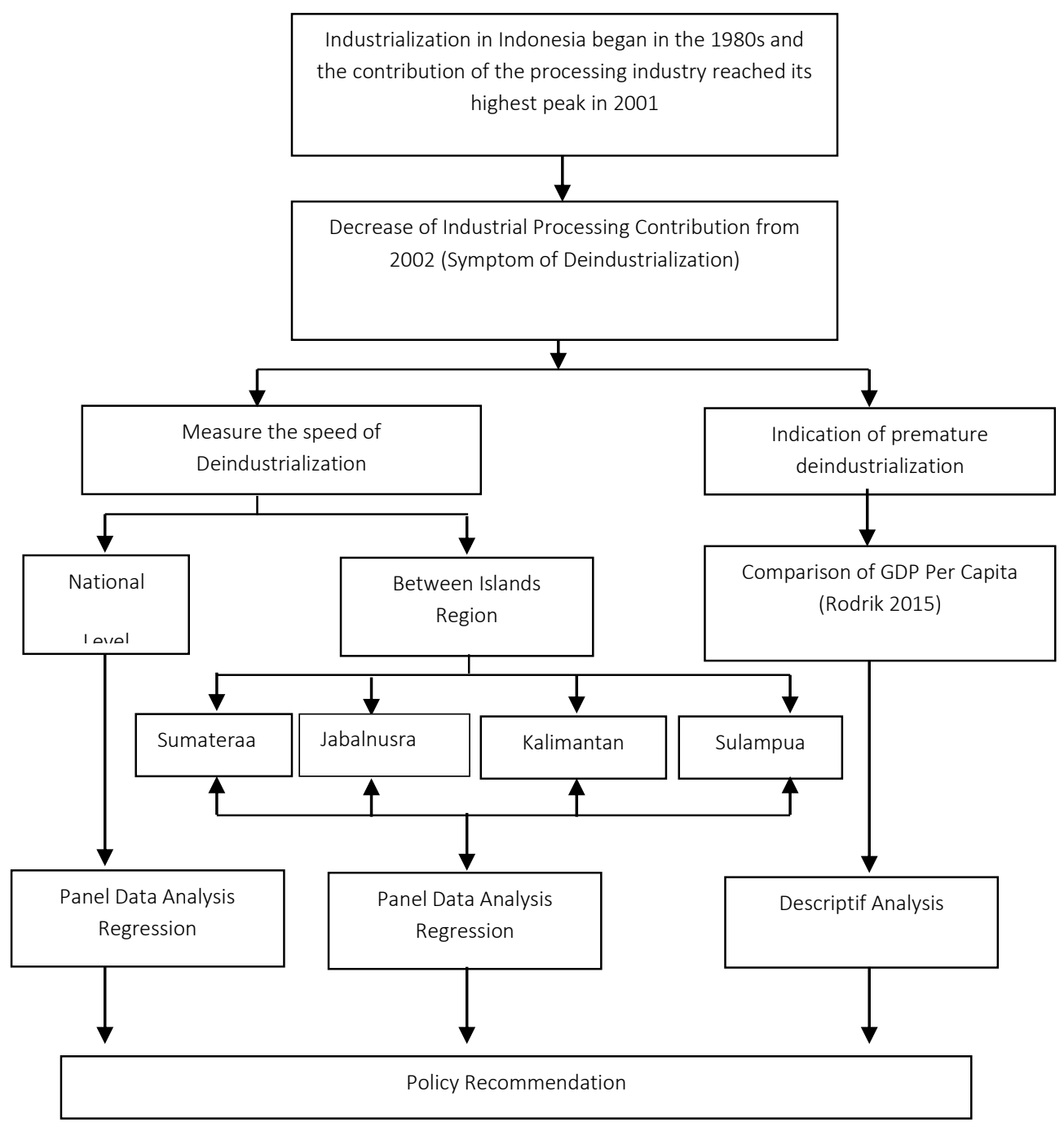

Figure 1. Research Framework 
Along with the process of industrialization in Indonesia in accelerating economic growth, there is a shift in the role of the agricultural sector towards the secondary sector and even tertiary sector. This is indicated by the declining role of the agricultural sector in the formation of GDP in recent years. In contrast, there is an increasing role of the manufacturing and service sectors in contributing to GDP. However, along with the change of economic structure in Indonesia, there is also a phenomenon in which the role of manufacturing industry sector has decreased in recent years.

Contrary to that fact, the symptoms that occur in the Indonesian economy today show the existence of deindustrialization symptoms that lead to negative deindustrialization. This is shown by the proportion of workers in the manufacturing sector to total workers experiencing negative growth since 2002. In addition, the growth of manufacturing industry sector output and manufacturing sector composition in GDP has been declining since 2002 .

\section{RESEARCH METHODS}

\section{Data Source}

This research uses secondary data from Badan Pusat Statistik (BPS)/Statistics Indonesia. These are are Gross Regional Domestic Product (GRDP) by sector and provinces, number of employment by sectors, and population.

The scope of the research is all of Indonesia's region. The newly formed provinces is returned to their parent province so the number of provinces used in the study were 26 provinces. For the purposes of inter-regional research in Indonesia, the grouping of islands is divided into 4 regions, these are Sumatra; Java, Bali, Nusa Tenggara (Jabalnusra); Kalimantan; Sulawesi, Maluku, Papua (Sulampua).

The research period is the data of each province for 30 years ie 1986-2015. The reason is Indonesia started the industrialization process since the late 1980s (Dasril 1993) and because of the availability of employment data (Sakernas) that is available since 1986. For the purposes of the research analysis, the time period is divided into three decades ie 1986-1995 (decade 1), 19962005 (2nd decade), and 2006-2015 (decade 3 ). The 3 decade grouping is based on the condition of the Indonesian economy, where in the first decade (1986-1995) was Indonesia's condition of industrialization and before the 1997 economic crisis; the second decade (1996-2005) was the condition of Indonesia experiencing crisis and recovery post economic crisis; and the third decade (2006-2015) was the period of recovery and development of the economic condition of Indonesia. 
Table 1. Variable names and units used in the research

\begin{tabular}{lllc}
\hline \multicolumn{1}{c}{ Variabel names } & \multicolumn{1}{c}{ Explanatory } & Source & Unit \\
\hline manemp & Manufacturing employment & BPS & $\%$ \\
totemp & Total employment & BPS & Orang \\
realmva & Real manufacturing value added & BPS & $\%$ \\
nommva & Nominal manufacturing value added & BPS & $\%$ \\
nomcap & Nominal per capita & BPS & Rupiah \\
\hline
\end{tabular}

The operational definitions of each of the variables used are as follows:

1. Manufacturing employment (manemp) is the proportion of workers in the manufacturing sector to total workers.

2. Total employment (totemp) is the sum of all employment

3. Nominal manufacturing value added (nommva) is the proportion of GRDP of manufacturing sector to total GRDP (at current prices)

4. Real manufacturing value added (realmva) is the proportion of GRDP of manufacturing sector to total GRDP (at constant prices)

5. Nominal per capita (nomcap) is the income per capita, as measured from the gross regional domestic income divided by the mid-year population.

\section{Method of Analysis and Data Processing}

The method of analysis was used in this study consists of descriptive analysis and panel data analysis. Descriptive analysis is used to provide a general overview of the characteristics of related variables in the study and to explain indications of premature deindustrialization.

Panel data analysis is performed to measure the speed of deindustrialization.
The collected secondary data is processed by the computer program package that is Microsoft Excel 2010. The data panel regression processing is done by using Eviews 9 program.

\section{Formulation of Research Model}

Referring to Rodrik's (2015) research, the regression model that will be used in this study are as follows:

$$
\begin{aligned}
& \operatorname{Ln}(\text { manemp })_{i t}=\alpha_{i}+ \\
& \beta_{1} \operatorname{Ln}(\text { totemp) })_{\text {it }}+ \\
& \beta_{2} \operatorname{Ln} \text { (totemp) }{ }_{\text {it }}^{2}+ \\
& \beta_{3} \operatorname{Ln}(\text { nomcap) })_{\text {it }}+ \\
& \beta_{4} \operatorname{Ln}(\text { nomcap) })_{\text {it }}^{2}+ \\
& \mathrm{D}_{2}+\mathrm{D}_{3}+\varepsilon_{\mathrm{it}} . .(11) \\
& \operatorname{Ln}(\text { nommva })_{i t}=\alpha_{i}+ \\
& \beta_{1} \operatorname{Ln}(\text { totemp) })_{\text {it }}+ \\
& \beta_{2} \operatorname{Ln}\left(\text { totemp) }{ }_{\text {it }}^{2}+\right. \\
& \beta_{3} \operatorname{Ln}(\text { nomcap) })_{\text {it }}+ \\
& \beta_{4} \operatorname{Ln}(\text { nomcap) })_{\text {it }}^{2}+ \\
& \mathrm{D}_{2}+\mathrm{D}_{3}+\varepsilon_{\mathrm{it}} . .(12) \\
& \operatorname{Ln}(\text { realmva })_{\mathrm{it}}=\alpha_{\mathrm{i}}+ \\
& \beta_{1} \operatorname{Ln}(\text { totemp) })_{\text {it }}+ \\
& \beta_{2} \operatorname{Ln}\left(\text { totemp) }{ }_{\text {it }}^{2}+\right. \\
& \beta_{3} \operatorname{Ln}(\text { nomcap) })_{\text {it }}+ \\
& \beta_{4} \operatorname{Ln}(\text { nomcap) })_{\text {it }}^{2}+ \\
& \mathrm{D}_{2}+\mathrm{D}_{3}+\varepsilon_{\mathrm{it}} . .(13)
\end{aligned}
$$

Where: Ln (manemp) it: the natural logarithm of the proportion of the manufacturing employment to the total; Ln (nommva) it: natural logarithm of the 
proportion of the manufacturing GDRP to total GRDP (nominal GRDP); Ln (realmva) $)_{\text {it: }}$ natural logarithm of the proportion of the manufacturing GDRP to total GRDP (real GRDP / constant); Ln (totemp) it: natural logarithm of the amount of employment; Ln (nomcap) it: $_{\text {: }}$ natural logarithm of GDP per capita; D2: dummy variable for $1996-2005\left(^{\text {nd }}\right.$ decade); D3: dummy variable for year
2006-2015 ( $3^{\text {th }}$ decade $)$; $\alpha$ : intercept; $\beta_{1}$, $\beta_{2} \ldots \beta_{4}$ : regression coefficients of each

independent variable; $\varepsilon_{\mathrm{it}}$ : error term; i: the i province; t: time period $(1986,1987$, ..., 2015).

The three regression models [equations (11), (12), and (13)] will be used in 5 different data sets. In detail, the data sets are presented in the following table.

Table 2. Group of research data

\begin{tabular}{lccc}
\hline $\begin{array}{c}\text { Group of research } \\
\text { data }\end{array}$ & $\begin{array}{c}\text { Number of Provinces } \\
\text { (i) }\end{array}$ & $\begin{array}{c}\text { Series data } \\
(\mathrm{t})\end{array}$ & $\begin{array}{c}\text { Number of } \\
\text { Observation }\end{array}$ \\
\hline Nasional & 26 Provinces & $1986-2015$ (30 years) & 780 \\
Sumatera & 8 Provinces & $1986-2015$ (30 years) & 240 \\
Jabalnusra & 8 Provinces & $1986-2015$ (30 years) & 240 \\
Kalimantan & 4 Provinces & $1986-2015$ (30 years) & 120 \\
Sulampua & 6 Provinces & $1986-2015$ (30 years) & 180 \\
\hline
\end{tabular}

\section{RESULTS AND DISCUSSION}

\section{Transformation of GDP Structure and Indonesian Workers}

During the period of 1986-2015, the economic structural transformation's scenario from agricultural based economy to manufacturing based economy began. The agricultural sector's contribution continued to decline and simultaneously the contribution of the manufacturing and services sectors increased.

Viewed from GDP, the manufacturing's contribution has reached its peak in the early of 2000, which amounted to $29.05 \%$ in 2001. After that, it continued to decline and reached $21.50 \%$ in 2015 . It means, the role of manufacturing's contribution has decreased in the Indonesian economy since 15 years ago. The opposite occurred in the service sector, from 1986 the contribution of the services sector tended to decline and fluctuate. It began to increase after 2010 and then continue to increase until now which reached $44.70 \%$

When viewed from the share of employment, the change of percentage in the contribution of manufacturing sector in the last 30 years showed no significant change, only about $5 \%$. While the percentage of employment in agriculture sector has decreased considerably during the last 30 years about $21.48 \%$. In contrast, a substantial increase occurred in the service sector which up by 15.56 $\%$ in the last 30 years. While other sectors did not experience significant percentage change.

It can be interpreted that there has been a shift in the number of workers (transformation of employment structures) between sectors, where the transformation of the largest employment structure occurs in the agricultural sector. However, the shift in employment is not entirely transferred or 
absorbed into the manufacturing sector but more to the service sector so that the growth rate of manpower in the manufacturing sector is relatively low with a relatively stable contribution's average about $12 \%$ from year to year.

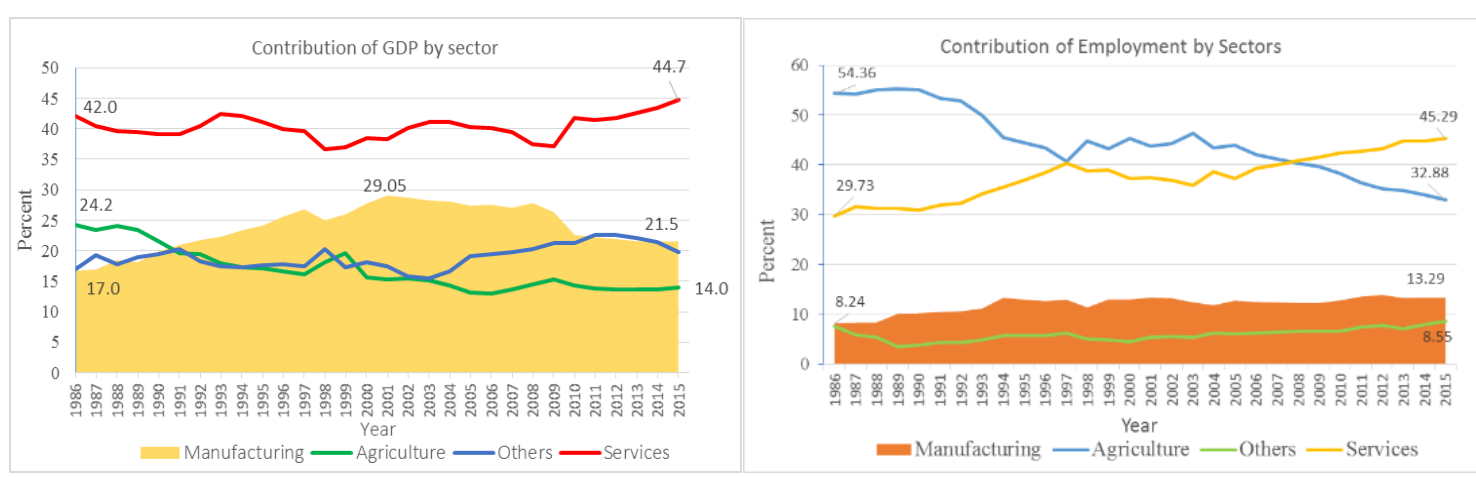

Source : Badan Pusat Statistik/Statistics Indonesia, processed

Figure 2. Share of agriculture, manufacturing, service \& other sectors to GDP and employment in Indonesia in 1986-2015 (\%)

\section{Profile of Manufacturing's Employment in Indonesia}

Based on Sakernas data of February 2015, manufacturing's employment is dominated by lower education junior high school which reach $58.36 \%$, while those with high school education equal to $36.38 \%$ and educated academy/diploma/bachelor degree only $5.25 \%$. The same composition also occurs in overall employment conditions.

ILO's analysis (2015) mentions that in Indonesia there has been a shortage of skilled workers and surplus employment and skill incompatibility. Skill incompatibilities are translated as workers who have a level of education that is too high or too low than that required by a particular job. The demand for highly qualified workers extends beyond existing employment supply. In addition, there is an excess supply of employment for those with a background of junior and senior high school education. This has led to a situation where there are many job vacancies in Indonesia filled with unqualified workers.

\section{Regional Share in GDP}

Each province has a leading sector that contributes the most in the creation of value added. Agricultural is the leading sector of most provinces (16 provinces) in Indonesia. Only 8 provinces have the leading sector of manufacturing. But these eight provinces are not the highest national GDP contributors. The highest eight national GDP contributors are Jawa Barat (23.78 $\%)$, Jawa Timur (17.93 \%), Jawa Tengah (12.95\%), DKI Jakarta (9.95\%), Banten (5.80\%), Riau (5.64\%), Sumatera Utara (4.19\%) and Kalimantan Timur (3.77 $\%)$. The eight largest contributing provinces of GDP accounted for $84 \%$ where the $70.40 \%$ is contributed by the provinces in Java's island.

In 2015, most of the value added of manufacturing contributed from the 
Jabalnusra region which amounted of $71.48 \%$, the remaining $18.79 \%$ was contributed by the region of Sumatra; $6.08 \%$ was contributed by Kalimantan and $3.65 \%$ was donated by Sulampua region.

\section{Selection of Panel Regression Model and Classic Assumption Test}

Based on the estimation model determination test and statistical test $\mathrm{F}$ (Chow Test), fixed effect model is selected as the most appropriate estimation model. This is in line with research conducted by Rodrik (2015).

The classical assumption test conducted on the research data group are normality test with histogram method: normality test, heteroscedasticity test with Breusch-Pagan LM method and autocorrelation test with Durbin-Watson stat method. The results of the classic assumption test found the existence of autocorrelation and heteroscedasticity on the five data groups and most of the distribution is not normal. To overcome the existence of autocorrelation heteroscedasticity the panel regression equation estimation using EGLS method with cross-section SUR is used. From the results of parameter estimation, not all of them show significant result at $\alpha=5 \%$.

\section{Inverted U-Shape's Analysis}

The Inverted U-Shape curve shows the relationship between income per capita (GDP per capita) and contribution of manufacturing by according to employment and GDP. The inverted U curve contains two aspects: the first shows how far to the right, which is how high per-capita income when the turning point happened. The second aspect shows how high the turning point, which is the contribution of the manufacturing to the employment and the GDP. Dependent variable used is the contribution of manufacturing to total employment and GDP and the explanatory variables are GDP per capita and GDP per capita squared (all in natural logs condition) (Rowthorn in Tragenna 2011).

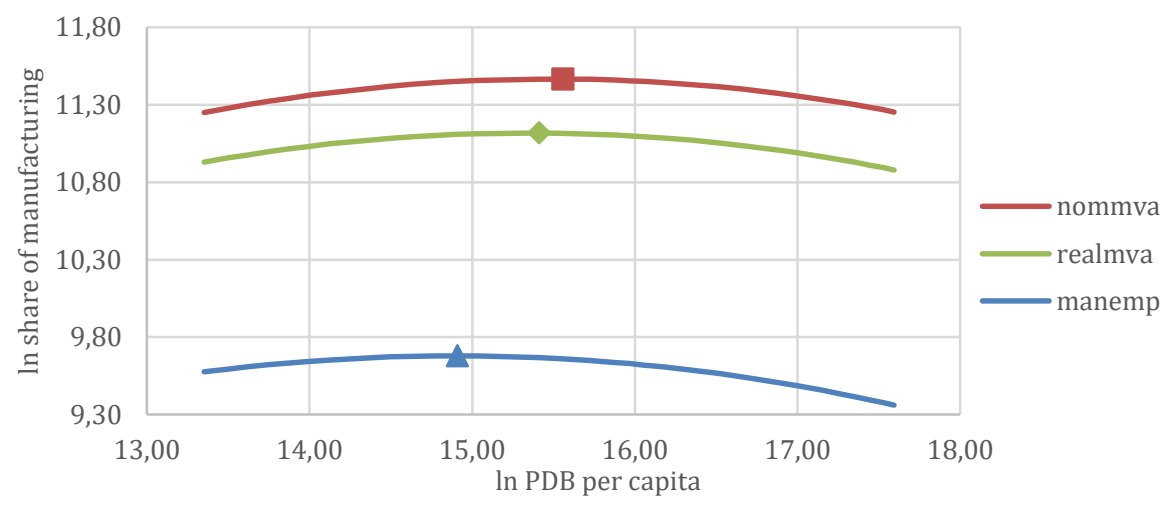

Source: Eviews Output, processed

Figure 3. Simulation of manufacturing's employment and manufacturing's GDP contributions to GDP per capita.

Figure 3 shows that the sequence of turning points manemp is slightly faster than nommva and realmva whereas the realmva turning point is faster than nommva. The contribution of the manufacturing has reached its 
maximum point and then declines as GDP increases per capita. The inverted U-shape curve indicates a deindustrialization. The manemp turning point referred to 1996 with GDP per capita of Rp 3 million, realmva referring to 1998 with GDP per capita of Rp 4.9 million, and nommva referring to 1999 with GDP per capita of Rp 5.7 million. Those years are around the year when Indonesia is experiencing an economic crisis.

Indonesia's economic crisis in 1997 had a big impact on economic performance because the crisis occurred not only due to the economic crisis, but also a political and social crisis. In the crisis period and after the crisis, according to real GDP, Indonesia's economic growth had experienced negative growth in 1998 then the following year showed improvement shown by the positive growth. The same condition also occurred in the manufacturing sector, but since 2005, the growth of manufacturing is smaller than the total economic growth. This is causing the contribution of the manufacturing has always declined until now although the GDP per capita has increased.

The contribution of manufacturing employment stagnate in the range of 12 $\%$ while the contribution of agriculture decreased sharply. It shows that the manufacturing does not absorb many employment transformation, thus the growth of manufacturing's employment is slower than the service sector which has a high contribution increase.

The deindustrialization based on the inverted U-Shape curve occurred earlier than the deindustrialization based on manufacturing's share in GDP (nominal). Manufacturing's share in
GDP (nominal) shows highest proportion occurred in 2001, then shows contribution's decrease (deindustrialization) since 2002. While based on inverted U-Shape curve, deindustrialization has occurred since 1997 (share of manufacturing's employment), $1999 \quad$ (real manufacturing's share in GDP), or 2000 (nominal manufacturing's share in GDP).

The research that showed non linear correlation between income per capita and the proportion of manufacturing employment on an inverted U-shape curve also shown by Metinara (2011). Her study concluded, that in line with increased income per capita, provinces with low and medium income per capita would increase the proportion of workers in the manufacturing. But at certain welfare limits, the increase in income per capita will reduce the proportion of workers in the manufacturing. This situation indicates in overall the economy in Indonesia is experiencing a slowdown due to shocks in the economic system.

\section{The Effect of Total Employment and GDP per Capita to Manufacturing's Employments Share and Manufacturing's share in GDP}

Data processing on national data groups using Eviews 9, yields a smaller F-statistic probability value of $\alpha=0.05$. From these results, it can be concluded that simultaneously independent variables significantly affect the independent variable. The results of the treatment also obtained a high adjusted $\mathrm{R}$-squared value which means that the independent variable is able to explain the dependent variable. 
Table 3. Results of panel data regression in national data group

\begin{tabular}{|c|c|c|c|}
\hline \multirow[t]{2}{*}{ Independent Variable } & \multicolumn{3}{|c|}{ Coefficient/prob. } \\
\hline & Ln(manemp) & Ln(nommva) & Ln(realmva) \\
\hline \multirow[t]{2}{*}{$\mathrm{C}$} & 11.763 & 3.319 & -0.931 \\
\hline & $0.000 * * *$ & $0.000 * * *$ & $0.035 * *$ \\
\hline \multirow[t]{2}{*}{ Ln Total Employment } & -3.453 & -2.760 & -2.224 \\
\hline & $0.000 * * *$ & $0.000 * * *$ & $0.000 * * *$ \\
\hline \multirow[t]{2}{*}{ Ln Total Employment squared } & 0.145 & 0.133 & 0.117 \\
\hline & $0.000 * * *$ & $0.000 * * *$ & $0.000 * * *$ \\
\hline \multirow[t]{2}{*}{ Ln GDP per capita } & 1.300 & 1.481 & 1.449 \\
\hline & $0.000 * * *$ & $0.000 * * *$ & $0.000 * * *$ \\
\hline \multirow[t]{2}{*}{ Ln GDP per capita squared } & -0.044 & -0.048 & -0.047 \\
\hline & $0.000 * * *$ & $0.000 * * *$ & $0.000 * * *$ \\
\hline \multirow[t]{2}{*}{ Decade 2 (1996-2005) } & -0.009 & -0.205 & -0.216 \\
\hline & 0.211 & $0.000 * * *$ & $0.000 * * *$ \\
\hline \multirow[t]{2}{*}{ Decade 3 (2006-2015) } & -0.108 & -0.423 & -0.429 \\
\hline & $0.000 * * *$ & $0.000 * * *$ & $0.000 * * *$ \\
\hline R-squared & 0.986 & 0.999 & 1.000 \\
\hline Adjusted R-squared & 0.985 & 0.999 & 1.000 \\
\hline F-statistic & $1,644.510$ & $17,006.490$ & $60,314.040$ \\
\hline Prob(F-statistic) & $0.000 * * *$ & $0.000 * * *$ & $0.000 * * *$ \\
\hline
\end{tabular}

Number of Province 26

26

26

Number of Obsevation

780

780

780

Source : Eviews Output (processed), $* * *$ ) significant in $\alpha=1 \%{ }^{* *}$ ) significant in $\alpha=$ $5 \% *$ ) significant in $\alpha=10 \%$

Table 3 shows the relationship between total employment and GDP per capita to the manufacturing's employments share and the manufacturing's share in GDP. The coefficient of total employment for three 
indicators (manemp, nommva, realmva) shows a negative value. This indicates a negative relationship between total employment with the three indicators where each increase of 1 unit of total employment will cause a decrease in the manufacturing's employments share, the manufacturing's share in GDP both in nominal and real of each coefficient value. The explanation can be understood by the phenomenon that every year there is an increase in the number of employment, except in 2010, but the addition of the number of employment is more into other sectors than manufacturing sector.

Mathematically, when the total value of the worker (denominator) increases but the number of manufacturing's employment (numerator) is relatively not increased then the proportion will shrink. The table also shows a positive relationship between GDP per capita and three indicators, that an increase of 1 unit of GDP per capita will increase the manufacturing's employments share, the manufacturing's share in GDP, both in nominal and real GDP of each coefficient value.

\section{The Speed of Deindustrialization in Indonesia}

Research about deindustrialization in Indonesia has been done by previous researchers such as Suwarman (2006); Dewi (2010); Metinara (2011); Rasbin (2011). Based on their research, it can be concluded, that deindustrialization happened in Indonesia is negative deindustrialization and not the natural impact of highly development process but due to shock caused by domestic factors and globalization.

To see the rate of deindustrialization in Indonesia dummy coefficient period of time is used in table
3. Coefficient value of Dummy variable indicates the following: (1) The magnitude of "industrialization level decline" or called deindustrialization based on the decade 1986-1995, (2) The negative value of the dummy variable coefficients that increase over time period (decade 1996-2005 and decade 2006-2015) indicates that deindustrialization was happening faster.

Rapidly deindustrialization occurred in nommva and realmva in the last two decades (1996-2005 and 20062015) compared to the first decade (1986-1995). The manemp indicator also shows deindustrialization in the last two decades but the dummy variable is not significant at $\alpha=5 \%$ even $\alpha=10 \%$ in decade 1996-2005, while decade 20062015 is significant at $\alpha=1 \%$. Compared to the decade 1986-1995, the manemp has a level of 0.108 points or $10.8 \%$ lower in the decade 2006-2015. This indicates the deindustrialization of the manufacturing's employments share in Indonesia.

This is the case with the nommva and realmva indicators. Compared to the decade 1986-1995, both indicators indicate a decline in the level of industrialization. Nommva indicator decreased the level of 0205 or $20.5 \%$ in the decade 1996-2005 then accelerated to 0423 points or $42.3 \%$ in the decade 2006-2015. Real-time indicators declined by 0.216 points or $21.6 \%$ in the decade 1996-2005 then fell back to 0.429 points or $42.9 \%$. Decrease in decade levels on both indicators indicates that the deindustrilization process is accelerating or more severe in Indonesia. Comparing the percentage velocity of these three indicators, realmva shows a slightly faster pace than nommva whereas manemp is slower than the other two indicators. 


\section{The Speed of Deindustrialization by Islands Region}

The results of parameter estimation by islands region show different results in each islands region. In general, the realmva indicator shows that deindustrialization in all regions is significant at $\alpha$ of $1 \%$, except in Jabalnusra in the 1996-2005 decade which is not significant. The nommva indicator shows deindustrialization in Sumatra and Sulampua at $\alpha$ of $1 \%$ and 5 $\%$, Kalimantan represents deindustrialization at $\alpha$ of $1 \%$ in the decade 2006-2015 whereas in the decade 1996-2005 was not significant. Based on nommva, Jabalnusra did not show significant deindustrialization. The manemp indicator shows Jabalnusra and Sulampua deindustrialized, although in Jabalnusra, in the decade 1996-2005, it was not significant.

For the region of Sumatera, the deindustrialization phenomenon is shown by the nommva and realmva indicators whereas the manemp indicator does not indicate deindustrialization. Deindustrialization's acceleration occured in the decade of 1996-2006 and decade 2006-2015 compared to the decade of 1986-1995. Acceleration of nommva indicator from 0.061 points or $6.1 \%$ to 0142 points or $14.2 \%$, indicates an acceleration of 0.081 points $(0.142-$ 0.061 ) or $8.1 \%$. Realmva indicators experienced a greater acceleration of 0.078 points or $7.8 \%$ to 0.182 points or $18.2 \%$, which means that the decade of 2006-2015 changed as much as 0.104 points or $10.4 \%$ over the previous decade.

For Jabalnusra region, deindustrialization was only shown in decade 2006-2015 from manemp and realmva indicator whereas in decade 1996-2005 was not significant at 95\% confidence interval. In the decade 2006-
2015, the indicator experienced a decline in the level of 0.091 points or $9.1 \%$ while the realmva indicator experienced a deeper decline in the level of 0.571 points or $57.1 \%$ against the decade 1986-1995.

For the Kalimantan region, the manemp indicator does not show significant deindustrialisation while the nommva and realmva indicators show faster deindustrialization. The nommva indicator showed a decline in industrialization rate of 0.180 points or $18 \%$ in the decade 2006-2015 against the decade 1986-1995. Realmva indicator showed a decline in industrialization level of 0.115 points or $11.5 \%$ in the decade 1996-2005 and higher in the next period of 0.274 points or $27.4 \%$.

Finally, the Sulampua region indicates an increasingly rapid deindustrialization on all indicators with a $90 \%$ confidence interval in the manemp and $99 \%$ in nommva and realmva. Compared to the decade of 1986-1995, the manemp indicator experienced a decline in the level of 0.166 points or $16.6 \%$ in the decade $1996-2005$ and increased by 0.084 points or $8.4 \%$ in the decade 2006-2015 to 0.250 points or $25 \%$ in the decade 20062015. The same is true with the nommva and realmva indicators, the difference being at the rate of deindustrialization in which the nommva and realmva deindustrialize deeper. In the decade 2006-2015, nommva decreased 0.559 points or $55.9 \%$ and realmva decreased the level of 0.571 points or $57.1 \%$ over the period 1986-1995. 
Table 4. Results of panel data regression in archipelago data group for dummy variable

\begin{tabular}{|c|c|c|c|c|c|}
\hline \multirow{3}{*}{ Islands Region } & \multirow[t]{3}{*}{ Indicator } & \multicolumn{4}{|c|}{ Periode } \\
\hline & & \multicolumn{2}{|c|}{ Decade 1996-2005 } & \multicolumn{2}{|c|}{ Decade 2006-2015 } \\
\hline & & Coeffisien & Prob & Coeffisien & Prob \\
\hline \multirow[t]{3}{*}{ Sumatera } & Ln(manemp) & 0.015 & 0.715 & 0.087 & 0.193 \\
\hline & $\operatorname{Ln}($ nommva $)$ & -0.061 & $0.042 * *$ & -0.142 & $0.002 * * *$ \\
\hline & Ln(realmva) & -0.078 & $0.003 * * *$ & -0.182 & $0.000 * * *$ \\
\hline \multirow[t]{3}{*}{ Jabalnusra } & Ln(manemp) & -0.009 & 0.752 & -0.091 & $0.044 * *$ \\
\hline & Ln(nommva) & 0.016 & 0.237 & -0.016 & 0.442 \\
\hline & Ln(realmva) & -0.228 & 0.259 & -0.571 & $0.005 * * *$ \\
\hline \multirow[t]{3}{*}{ Kalimantan } & $\operatorname{Ln}($ manemp) & 0.208 & $0.028 * *$ & -0.157 & 0.288 \\
\hline & $\operatorname{Ln}($ nommva) & -0.058 & 0.116 & -0.180 & $0.002 * * *$ \\
\hline & Ln(realmva) & -0.115 & $0.005^{* * *}$ & -0.274 & $0.000 * * *$ \\
\hline \multirow[t]{3}{*}{ Sulampua } & Ln(manemp) & -0.166 & $0.067 *$ & -0.250 & $0.062 *$ \\
\hline & $\operatorname{Ln}($ nommva) & -0.239 & $0.002 * * *$ & -0.559 & $0.000 * * *$ \\
\hline & Ln(realmva) & -0.228 & $0.005^{* * * *}$ & -0.571 & $0.000 * * *$ \\
\hline
\end{tabular}

Based on the above analysis, it can be concluded that the realmva indicator shows more of the deindustrialization's existense in the archipelago of Indonesia and also shows the rate of deindustrialization speed is greater than the other two indicators.

The inter-island comparison analysis can be seen by comparing the indicator coefficient values between islands. Based on the manemp indicator, the speed rate of deindustrialization in Sulampua is faster than Jabalnusra. Likewise with the indicator nommva, Sulampua deindustrialization faster than Kalimantan and Sumatera while based on realmva indicator, Sulampua and Jabalnusra have the same speed. It shows that the area of Sulampua is the hardest region that is deindustrialized as indicated by the high coefficient value in the three indicators.

\section{Identification of Premature deindustrialization}

Premature deindustrialization brings serious consequences both to the economy and to politics. On the economic side, it reduces the potential for economic growth and the possibility of convergence with income levels from developed countries. The political consequences of premature deindustrialization can make democratization more likely to be fragile (Rodrik 2015).

Some premature deindustrialization definitions put forward by previous researchers can draw the conclusion that premature deindustrialization is a deindustrialization that occurs when the level of GDP per capita of a country is well below the GDP of developed countries when developed countries are in the process of industrialization and the country is transformed into a service- 
based country without undergoing a mature industrialization process. Thus, to analyze whether premature deindustrialization occurred in Indonesia required three data. The first is the GDP per capita of Indonesia at the peak of the highest industrialization which will be seen from the manufacturing's share in GDP at current prices. Secondly, the GDP per capita of some developed countries when it reaches the peak of industrialization. Third, the magnitude of the manufacturing's share in GDP based on current prices at the peak of industrialization.

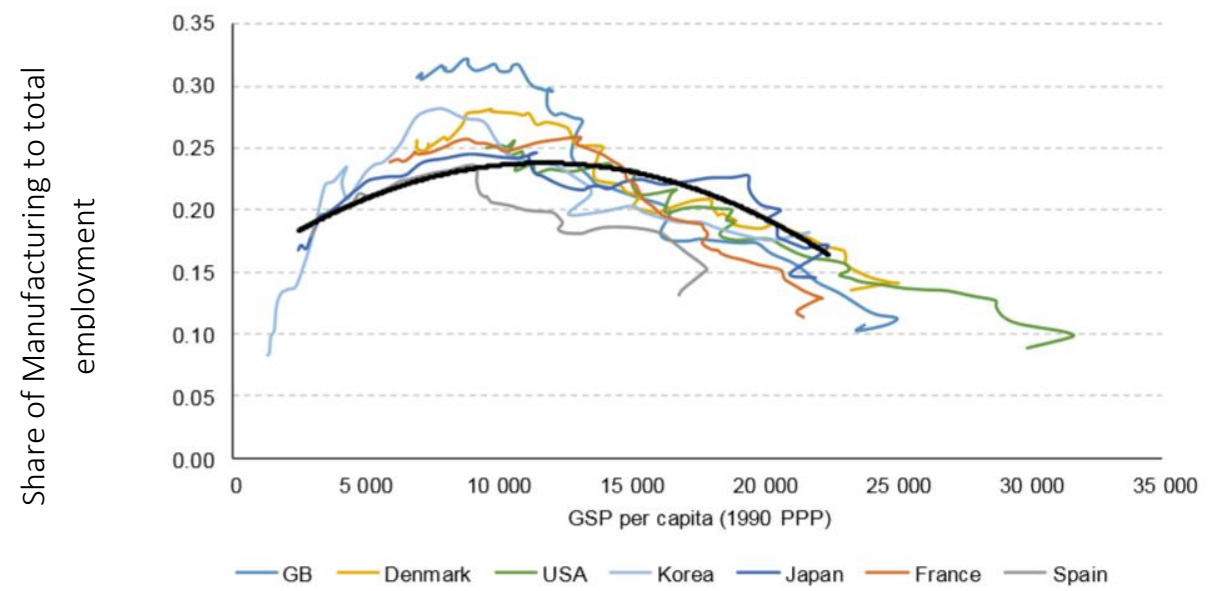

Source : Castillo and Neto (2016)

Figure 4. Deindustrialization at 7 developed country

Castillo and Neto (2016) show GDP per capita and the manufacturing's employments share to total workers in the seven selected developed countries. The seven developed countries reached the peak of industrialization with turning points on GDP per capita of about US \$ 10,000 -US $\$ 15,000$. In Rowthorn
(1994) calculated from 70 countries, turning points are approximately US \$ 12,000 per capita (1991 PPP), which most OECD countries reached that point in the 1970s. Rowthorn and Coutts (2004) estimated turning points of approximately US \$9,500 per capita (1995 PPP).

Table 5. Manufacturing's share in GDP and per capita GDP Year 2001, 2005, 2010 and 2015

\begin{tabular}{lrrrr}
\hline \multicolumn{1}{c}{ Details } & \multicolumn{1}{c}{2001} & \multicolumn{1}{c}{2005} & \multicolumn{1}{c}{2010} & \multicolumn{1}{c}{2015} \\
\hline Manufacturing's share in GDP (\%) & 29.05 & 27.4 & 22.6 & 21.5 \\
GDP Per Capita (PPP) & & & & \\
Indonesia & $4,812.06$ & $6,088.88$ & $8,294.05$ & $11,035.09$ \\
High income countries & $28,548.10$ & $33,783.68$ & $38,977.51$ & $44,695.99$ \\
Middle income countries & $4,134.02$ & $5,572.63$ & $8,224.87$ & $10,820.63$ \\
Lower middle income countries & $2,690.03$ & $3,519.93$ & $4,884.37$ & $6,423.28$ \\
Low income countries & 885.84 & $1,034.20$ & $1,333.76$ & $1,644.77$ \\
\hline
\end{tabular}

Source : World Development Indicators, World Bank 
Indonesia achieved the highest manufacturing's share in GDP in 2001 at $29.05 \%$ based on GDP at current prices. At that time, Indonesia's GDP per capita only reached US \$ 4,812.06 (PPP). Compared to Castillo and Neto data (2016), Indonesia's per capita GDP is well below the GDP per capita of developed countries as developed countries reach the peak of industrialization. This indicates an indication of premature deindustrialization in Indonesia. Especially in fifteen years, Indonesia is still classified as a country with per capita national income that is classified as middle income (middle income) or closer to middle income lower (lower middle income). The condition of GDP per capita that has not shifted or out of middle income is indicated as a danger of deindustrialization called middle income trap.

In addition to comparing Indonesia's GDP per capita level against developed countries, indications of premature deindustrialization can be seen from the maturity of industrialization. The maturity level of industrialization can be seen from the results of MGI (2012) study in Figure 5 below, where a country will experience a mature industrialization if its manufacturing's GDP contribution has reached 30 to $40 \%$ and its GDP per capita is above $\$ 7000$ - $\$ 10,000$.

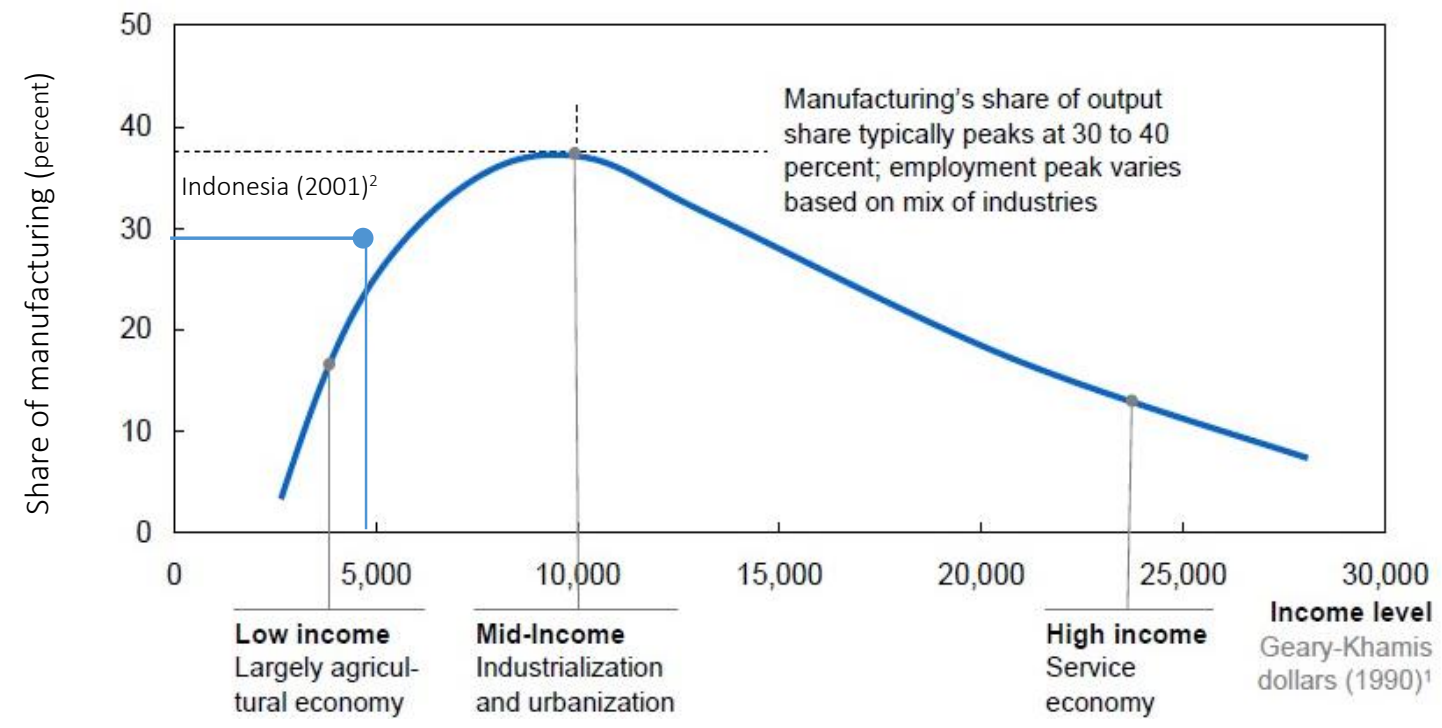

Source : MGI (2012), ${ }^{1)} 1990$ Geary-Khamis dollar calculated based on kurs and Puchasing Power Parity $(\mathrm{PPP}),{ }^{2}$ Simulate Indonesia's potition when reaches the peak of industrialization

Figure 5. The manufacturing's share in GDP uses the research according to the level of GDP per capita (1990 Geary-Khamis dollars) following the inverted U-shape curve 
Based on research conducted by MGI (2012) it also concluded that the service sector can not contribute significantly to GDP before GDP per capita is above $\$ 7000-\$ 10,000$. The above graph is the evolution cycle of a healthy country's economic growth, the evolution of its economic growth will follow an inverted $U$ curve, that is, when the industry's share of GDP exceeds 30 $\%$ to $40 \%$ and GDP per capita is above $\$ 7000$ - \$10,000 then the economy begins to shift to direction of the services sector.

Considering the above condition, Indonesia's GDP per capita is at middle income level and the contribution of manufacturing industry sector which is still below $30 \%$ indicates that Indonesia is experiencing early indication of deindustrialization. It is also reinforced from the results of previous research that the deindustrialization that occurred in Indonesia is a negative deindustrialization which occured due to shock that comes from either domestic or global.

\section{CONCLUSION AND RECOMENDATIONS}

\section{Conclusion}

Based on the analysis and previous discussion it can be drawn some conclusions as follows:

1. Inverted U-shape shows that deindustrialization has occurred in Indonesia in the period around the 1997 economic crisis, in line with the literature which mentions deindustrialization was caused by shock or negative deindustrialization.

2. Panel data regression results, shows a negative relationship between total employments with all three indicators. The explanation can be understood by the phenomenon that every year there is an increase in the number of employments, except in 2010 , but the addition of the number of employments is more into other sectors other than the manufacturing.

3. Rapid deindustrialization in Indonesia has occurred as indicated by the contribution of both nominal and real manufacturing's share in GDP (nommva and realmva).

4. Rapid deindustrialization also occurs in all islands. From the results of comparison analysis between islands by comparing the magnitude of coefficients inter-island indicators, it can be concluded that the area of Sulampua is the worst affected areas of deindustrialization which shown by the high coefficient on the three indicators.

5. Indications of premature deindustrialization occur in Indonesia where GDP per capita and the manufacturing'share sector are still relatively low.

\section{Recommendations}

Related to the importance of the manufacturing sector as a motor of development or engine of growth, then:

1. Considering that deindustrialization has occurred more than 15 years ago, the government needs to establish a prompt and appropriate step to rebuild industrialization (reindustrialization) in Indonesia so that deindustrialization can be immediately overcome. With reindustrialization, it is expected that the role of the manufacturing as a growth engine will again encourages other sectors to grow higher so as to increase economic growth and GDP per capita of Indonesia and ultimately improve the welfare of Indonesian people into developed countries. 
2. The development of manufacturing needs to be done equally throughout the archipelago in Indonesia considering all the islands are deindustrialized. The priority of development of manufacturing is done outside Jabalnusra especially Sulampua to downplay the imbalance of development in Indonesia, where industrialization is identical with development.

3. To increase the income per capita of the community through the manufacturing sector, the development of manufacturing should be directed to employment intensive manufacturing considering the composition of employment in Indonesia dominated by secondary education.

4. Increasing human resources needs to be done through education and skills so that future human resources have higher quality (highly skill-intensive). With high quality of resources, then human resources by itself will be ready to enter the service sector that has high productivity and tradeable such as information and communication technology (ICT) and financial sector and other service sectors that can replace the role of the manufacturing as a growth engine .

\section{REFERENCES}

[BPS] Badan Pusat Statistik. 2009. Klasifikasi Baku Lapangan Usaha di Indonesia. Jakarta (ID).

Basri F. 2013. Indonesia terjerat middle income trap. https://faisalbasri.com/2013/08/1 0/indonesia-terjera-middleincome-trap/. [2017 Januari 2].

Castillo M, Neto AM. 2016. Premature deindustrialization in Latin
America. ECLAC Production Development Series No. 205

Dasgupta S, Singh A. 2006. Manufacturing, services and premature deindustrialization in developing countries: a kaldorian analysis. UNU-WIDER. United Nations University Research Paper.

Dasril ASN. 1993. Pertumbuhan dan Perubahan Struktur Produksi Sektor Pertanian dalam Industrialisasi di Indonesia, 1971-1990 [disertasi]. Program Pascasarjana, Institut Pertanian Bogor.

Dewi DA. 2010. Deindustrialisasi di Indonesia 1983-2008: analisis dengan pendekatan kaldorian [tesis]. Program Pascasarjana, Institut Pertanian Bogor.

Effendi BS. 2016. Deindustrialisasi ancam Indonesia jadi negara gagal.

http://www.kompasiana.com/bo b911/deindustrialisasi-ancamindonesia-jadi-negaragagal_5832d60cf0967340058b4 571. [2017, Januari 2].

[ILO] International Labour Organization. 2015. Tren Ketenagakerjaan dan Sosial Di Indonesia 2014-2015: Memperkuat Daya Saing dan Produktivitas Melalui Pekerjaan Layak/Kantor Perburuhan Internasional - Jakarta (ID).

Jalilian H, Weiss J. 2000. Deindustialization in Sub-Saharan: myth or crisis? Journal of American Economies. Vol. 9(1): 24-43.

Kollmeyer C. 2009. Explaining deindustrialization: how affluence, productivity growth, 
and globalization diminish manufacturing employment. American Journal of Sociology. Vol. 114(6): 1644-74.

Metinara S. 2011. Faktor-faktor yang memengaruhi deindustrialisasi di Indonesia tahun 2000-2009. [tesis]. Program Pascasarjana, Institut Pertanian Bogor.

[MGI] McKinsey Global Institute. 2012. Manufacturing The Future: The Next Era of Global Growth And Innovation. McKinsey \& Company

Priyarsono DS. 2011. Dari Pertanian ke Industri Analisis Pembangunan dalam Perpekstif Regional. Bogor (ID). IPB Press.

Rasbin. 2011. Gejala deindustrialisasi dan dampaknya terhadap perekonomian Indonesia. Kajian Vol 16 no 2

Rodrik D. 2015. Premature Deindustrialization. NBER Working Paper No. 20935.

Rowthorn R dan Coutts K. 2004. Deindustrialisation and the balance of payments in advanced economies. Cambridge Journal of Economics.

Rowthorn R, Ramaswamy R. 1997. Deindustrialisation: causes and implications. IMF Working Paper no. 97/42, Washington: International Monetary Fund.

Rowthorn R, Ramaswamy R. 1999. Growth, trade, and deindustrialization. IMF Staff papers, 46 (1), 18-41.

Singh A. 1977. UK industry and the world economy: a case of deindustrialization? Cambridge Journal of Economics. Vol. 133(2): 113-136.

Suwarman W. 2006. Faktor-faktor apakah yang mendorong terjadinya proses deindustrialisasi di Indonesia. [tesis]. Program Pascasarjana, Universitas Indonesia.

Tregenna F. 2009. Characterizing deindustrialization: an analysis of changes in manufacturing employment and output internationally. Cambridge Journal of Economics. Vol. 33.

Tregenna F. 2011. Manufacturing Productivity,

Deindustrialization, and Reindustrialization. Working Paper No. 2011/57.

Tregenna F. 2015. Deindustrialization, struktural change and sustainable economic growth. UNIDO. Working Paper No. 2/2015.

Yani I. 2010. LIPI: Indonesia berjalan ke arah deindustrialisasi. http://m.kontan.co.id/news/lipiindonesia-berjalan-ke-arahdeindustrialisasi-1. [2016 December 24].

Worldbank. 2016. World Development Indicators. http://data.worldbank.org. [2016 December 20]. 